\author{
Ariel Orzełek \\ (Uniwersytet Marii Curie-Skłodowskiej w Lublinie) \\ https://orcid.org/0000-0001-5360-464X
}

\title{
Minimalizm i maksymalizm a „stommizm”. Refleksje nad książką Radosława Ptaszyńskiego, Stommizm. Biografia polityczna Stanisława Stommy, Wydawnictwo „Znak”, Kraków 2018, ss. 720
}

\footnotetext{
Minimalism and Maximalism or "Stommism". Reflection on the Radosław Ptaszyński's Book, "Stommizm. Biografia polityczna Stanisława Stommy" ["Stommism. Political Biography of Stanisław Stomma"], published by "Znak", Cracow 2018, pp. 720
}

\section{STRESZCZENIE}

Książka Radosława Ptaszyńskiego poświęcona postaci i myśli politycznej Stanisława Stommy dotyka istotnych problemów realizmu politycznego w polskiej tradycji intelektualnej oraz zagadnień dotyczących katolików świeckich w okresie powojennym. Ukazano w niej postać S. Stommy jako polityka i publicysty, który musiał się zmierzyć z najważniejszymi dylematami polskiej inteligencji w XX w. Był twórcą własnego systemu myślowego, określanego mianem „stommizmu”, który zajmował autonomiczną pozycję wobec nurtów ugodowych, realistycznych i romantycznych. Pomimo pewnych zarzutów dotyczących przede wszystkim kontekstu ustaleń publikację tę uznać można za wysoce wartościową.

Słowa kluczowe: biografia, myśl polityczna, publicystyka, realizm polityczny, Stanisław Stomma

Stanisław Stomma należał do postaci, które jedną polityczną decyzją określiły obraz swej biografii i koncepcji w powszechnym odbiorze. Jego głośny, „rejtanowski” gest w Sejmie PRL w 1976 r., kiedy wstrzymał się od głosowania nad poprawkami do Konstytucji stanowiącymi o przewodniej w państwie roli PZPR oraz o "sojuszu” ze Związkiem Sowieckim, miał jednak znaczenie nie tylko symboliczne. Był symptomem ostatniego etapu procesów rozłamowych w ruchu "Znak", prowadzących do uzależnienia 
legalnych ugrupowań katolickich od władz PRL. Zjawisko to popychało niezależnych intelektualistów katolickich w kierunku koncepcji zdecydowanie opozycyjnych. Znamienne, że przeciwnikiem gestu Stommy był m.in. Konstanty Łubieński - niegdyś jeden z czołowych katolickich konserwatystów ${ }^{1}$, w 1956 r. przeciwnik Bolesława Piaseckiego, a rok później Jana Frankowskiego, który dążył do uzależnienia rodzącego się Chrześcijańskiego Stowarzyszenia Społecznego od „popaździernikowej” ekipy. Stanisław Stomma okazał się w 1976 r. ostatnim niezależnym politykiem katolickim w PRL, stojącym na gruncie pewnej współpracy z władzami. Znaczenie jego koncepcji dla rozwoju myśli politycznej katolików świeckich w okresie powojennym jest niebagatelne, zaś on sam niejednokrotnie brał udział w sporach ideowych, definiujących przestrzeń między minimalizmem a maksymalizmem (wpisujących się w konflikt między tendencjami realistycznymi a romantycznymi w polskiej tradycji intelektualnej).

Książkę Radosława Ptaszyńskiego poświęconą jego postaci należy przyjąć z uznaniem. Wynika to nie tylko z faktu, że oprócz studium porównawczego koncepcji Stanisława Stommy i Janusza Zabłockiego ${ }^{2}$ nie istniała monografia poświęcona tej postaci. Historiografia Polski powojennej cierpi na deficyt biografii i opracowań koncepcji politycznych wszystkich grup katolików świeckich (grupy „Dziś i Jutro” oraz „PAX”, środowiska „Tygodnika Warszawskiego”, ChSS, „Znaku”, Ośrodka Dokumentacji i Studiów Społecznych oraz „neo-Znaku”). Wystarczy stwierdzić, że na próżno można szukać książek poświęconych Andrzejowi Micewskiemu, Wojciechowi Kętrzyńskiemu, Dominikowi Horodyńskiemu, Jerzemu Hagmajerowi, Konstantemu Łubieńskiemu, Janowi Frankowskiemu, Zygmuntowi Przetakiewiczowi, Ryszardowi Reiffowi. Oprócz publikacji dotyczących postaci i koncepcji Bolesława Piaseckiego ${ }^{3}$ oraz, świetnych zreszta, opracowań dotyczących jego ruchu i środowiska „Znaku”4 czytel-

1 W 1933 r. Konstanty Łubieński na łamach krakowskiego „Czasu” domagał się zdecydowanej walki obozu zachowawczego z nurtami lewicowymi w polskim życiu politycznym, społecznym i kulturalnym. K. Łubieński, Około „Wiadomości Literackich”. Do czynu, „Czas" 19 II 1933, 85, 41, s. 4.

2 M. Strzelecka, Między minimalizmem a maksymalizmem. Dylematy ideowe Stanisława Stommy i Janusza Zabłockiego, Toruń 2015.

3 A. Dudek, G. Pytel, Bolestaw Piasecki. Próba biografii politycznej, Londyn 1990; J. Engelgard, Wielka gra Bolestawa Piaseckiego, Warszawa 2008; idem, Bolestaw Piasecki 1939-1956, Warszawa 2015; A. Jaszczuk, Ewolucja ideowa Bolesława Piaseckiego 1932-1956, Warszawa 2005.

4 A. Friszke, Między wojna a więzieniem 1945-1953. Młoda inteligencja katolicka, Warszawa 2015; J. Majchrowski, Geneza politycznych ugrupowań katolickich. Stronnictwo Pracy, grupa "Dziś i Jutro", Paris 1984; A. Micewski, Wspótrzadzić czy nie kłamać? Pax i Znak w Polsce 19451976, Paryż 1978; Sensus catholicus. Katolicy świeccy w Polsce Ludowej. Postawa - aktywność myśl. Studia i szkice, red. R. Ptaszyński, T. Sikorski, Toruń 2004. Na wyróżnienie zasługuje praca Piotra Kosickiego o personalistycznych korzeniach koncepcji środowisk katolików 
nik nie może liczyć na kompleksowe prace dotyczące wybranych zagadnień z dziejów i myśli środowisk katolików świeckich.

Radosław Ptaszyński postawił sobie zadanie ambitne i trudne do realizacji. Stanisław Stomma należał do tych polskich polityków, publicystów i myślicieli, którzy dojrzewali w II Rzeczypospolitej, doświadczali okrucieństw wojny, zaś większość ich życia przypadła na okres powojenny. S. Stomma, podobnie jak Aleksander Bocheński czy Jerzy Hagmajer, był także obserwatorem życia politycznego III Rzeczypospolitej, mogącym skonfrontować ową nową suwerenność ze swymi doświadczeniami z niepodległej, międzywojennej Polski.

Sam Autor w dziedzinie "stommizmu” ma już znaczący dorobek ${ }^{5}$, $\mathrm{w}$ tym niedawno wydaną trzytomową edycję pism wybranych myśliciela $^{6}$. Z pewnością znajomość publicystyki Stommy jest podstawowym wymogiem badań nad jego postacią. Niemniej jednak R. Ptaszyński dokonał także licznych kwerend archiwalnych, które pozwoliły mu nie tylko uściślić wiele zagadnień dotyczących koncepcji i biografii bohatera książki, ale także nakreślić szerokie tło kontekstowe. Autor korzystał z bogatych archiwów Instytutu Pamięci Narodowej oraz akt Stanisława Stommy i polityków z nim związanych, zgromadzonych w Archiwum Akt Nowych i Bibliotece Narodowej w Warszawie. Sięgnął również do archiwów prywatnych i kościelnych, wprowadzając do obiegu naukowego wiele nowych ustaleń. Wychwyceniu niuansów biograficznych służyły poszukiwania $\mathrm{w}$ archiwach litewskich, natomiast zakulisowa działalność dyplomatyczna Stommy została ukazana m.in. dzięki kwerendom w archiwach niemieckich i francuskich. Wysoko też należy ocenić wykorzystanie materiałów prasowych oraz mocne oparcie rozważań na literaturze przedmiotu.

Stanisław Stomma był związany z ruchami politycznymi, które miały znaczący wpływ na kształtowanie postaw polskiej inteligencji w XX w., toteż uwidocznienie $\mathrm{w}$ tym procesie roli wieloletniego posła na Sejm PRL należy uznać za jedno z najważniejszych zadań badawczych stojących przed jego biografem.

świeckich w Polsce Ludowej. P.H. Kosicki, Personalizm po polsku. Francuskie korzenie polskiej inteligencji katolickiej, Warszawa 2016.

5 R. Ptaszyński, Powstanie Koła Posłów "Znak" w projekcie neopozytywizmu Stanisława Stommy, w: Wybory i referenda w PRL, red. S. Ligarski, M. Siedziako, Szczecin 2014, s. 631647; idem, Stanistaw Stomma. Szkic do portretu katolickiego intelektualisty, w: Sensus catholicus. Katolicy, s. 402-437; idem, "Stommizm" - racjonalizm i sztuka kompromisu, "Znak" lipiecsierpień 2015, 722-723, s. 104-108.

6 S. Stomma, Pisma wybrane, t. 1: 1931-1939, t. 2: 1946-1975, t. 3: 1976-2003, red. R. Ptaszyński, Kraków 2017. 
Konstrukcja pracy ma charakter chronologiczny, jednakże kolejne cezury wyznaczają kwestie nie tylko stricte życiorysowe, ale też te dotyczące ewolucji myśli politycznej Stommy. Jest to zabieg w pełni zrozumiały w przypadku biografii postaci, której głównym polem aktywności była polityczna refleksja, przekładająca się dopiero na konkretne działania. Warte uwagi jest to, że chociaż tytuł książki brzmi Stommizm. Biografia polityczna Stanisława Stommy, to nagłówki na stronach publikacji mówią już o „myśli politycznej Stanisława Stommy”. Nie wiadomo, czy jest to zabieg celowy, czy omyłka edytorska, niemniej jednak faktem jest, że książka R. Ptaszyńskiego meandry życia polityka rozpatruje przede wszystkim przez pryzmat jego ideowych wyborów.

Stanisław Stomma urodził się w 1908 r. na Kowieńszczyźnie, co miało niebagatelny wpływ na jego światopogląd. Rodzina Stommów należała do tego odłamu polskiej, kresowej, ziemiańskiej inteligencji, który odrzucał koncepcje insurekcyjne, wierząc w możliwość porozumienia z Moskwą. Pokolenie to różniło się stanowczo od pokolenia Józefa Piłsudskiego i Władysława Studnickiego w swym stosunku do caratu. Ojciec przyszłego publicysty i polityka wyznawał przy tym koncepcje „litwomańskie", w czym zupełnie różnił się od swej żony. Sam Stanisław był bliższy poglądom swego ojca, co, jak się wydaje, mogło mieć wpływ na jego późniejsze refleksje dotyczące potrzeby pojednania polsko-niemieckiego. Przyszły poseł nie widział w Litwinach wroga, będąc rzecznikiem pokojowego współżycia narodowości na kresach północno-wschodnich. Jak się wydaje, można go określić mianem „krajowca”. Szkoda, że Radosław Ptaszyński, pisząc interesująco o dzieciństwie i młodości swego bohatera w tym właśnie kontekście, nie pokusił się o te dwie ostatnie konstatacje. Można bowiem wyrazić przekonanie, że Stomma w ujmowaniu Litwy bliski był nie tylko swemu przyjacielowi, Czesławowi Miłoszowi, ale także wybitnemu patriocie tych ziem (nienawidzącemu wszelkich nacjonalizmów) Józefowi Mackiewiczowi ${ }^{7}$.

Radosław Ptaszyński trafnie zauważył, że Stanisław Stomma w swej fascynacji Józefem Piłsudskim wyrażał, wyznawaną już wcześniej, syntezę romantyzmu i pozytywizmu. Polegała ona na szacunku dla heroicznej, narodowej przeszłości, ale równocześnie na uznaniu obiektywnych uwarunkowań. Zatem, zafascynowany czynem legionowym, ale też uznający znaczenie etyki w polityce, oburzał się, tak jak jego mistrz, Marian Zdziechowski, z powodu sprawy gen. Włodzimierza Zagórskiego i wyborów brzeskich. Niemniej jednak konsekwentnie popierał obóz sanacyj-

7 Czego najpełniejszym wyrazem jest jego zbiór reportaży z tych ziem. J. Mackiewicz, Bunt rojstów, Londyn 2011. 
ny (s. 43-44). Do rozważań Autora warto dodać następującą hipotezę: być może stosunek Stommy do Piłsudskiego, w którym górę brał swoiście pojmowany interes państwa nad moralnymi obiekcjami, jest prawzorem jego postawy wobec komunizmu, gdzie musiał, na większą rzecz jasna skalę, lawirować między politycznym realizmem a wiernością imponderabiliom (do refleksji takiej Autor zdaje się skłaniać dopiero w zakończeniu pracy: s. 663). Przyczynkiem do tego jest też stosunek Stommy do konfliktu wawelskiego, kiedy (podobnie jak A. Bocheński ${ }^{8}$ ) zajmując stanowisko pozornie bliskie piłsudczykom, równocześnie potępiał antykościelną propagandę związaną z decyzją metropolity krakowskiego (s. 69).

Godne uwagi są także rozważania Ptaszyńskiego o ruchu „Odrodzenie”, w którym Stomma odgrywał znaczącą rolę. Miał on wpływ na ewolucję ideową owego środowiska z pozycji endeckich i antysemickich na piłsudczykowskie i personalistyczne. Zgodzić się należy z konstatacją że „Odrodzenie" było w istocie protoplastą "Znaku”, mając wpływ na kształtowanie ideowe Stanisława Stommy, Jerzego Turowicza czy Antoniego Gołubiewa. Warto dodać, że w „Odrodzeniu”, obok wspomnianego przez Autora Henryka Dembińskiego, który wkrótce uległ fascynacji zarówno marksizmem, jak i stalinizmem, działał również Jan Frankowski, jeden z czołowych działaczy katolickich w Polsce Ludowej i przeciwnik ruchu "Znak"9.

Wiąże się $\mathrm{z}$ tym $\mathrm{w}$ dużej mierze analiza przedwojennej publicystyki Stommy, jakiej dokonał Ptaszyński. Starał się on ukazać swoiste "grawitowanie" swego bohatera ku koncepcjom prawicowym, które sam Stomma tłumaczył chęcią przyciągnięcia do „Odrodzenia” grup narodowców, a które później oceniał jako zbyt daleko idące. Szczególnie godne uwagi są jego koncepcje w kwestii żydowskiej - odżegnując się od antysemityzmu „pogromowego", równocześnie uznawał za konieczną walkę z pewnymi kręgami Żydów, które uznawał za nihilistyczne (s. 66-67). Jest to przyczynek do ducha epoki - dodać należy, czego Ptaszyński nie czyni, że takie koncepcje były dość rozpowszechnione i wyznawali je także inni, wrażliwi wszak na kwestie mniejszościowe, publicyści ${ }^{10}$. Stanisław Stomma, cechują-

8 A. Bocheński, Czemu Wieniawa nie strzegt, jak wierny syn, tej trumny?, „Słowo" 22 VI 1937, 16, 174 (4738), s. 1-2.

9 A.W. Kaczorowski, Jan Frankowski, w: Słownik biograficzny katolicyzmu społecznego w Polsce, t. 1: A-J, red. R. Bender, Lublin 1994, s. 134-135.

10 A. Bocheński, Nasze nie ich, „Bunt Młodych” 15 VII 1933, 4, 43, s. 1; idem, O imperialiźmie, o Skiwskim i o sprawie żydowskiej, "Polityka" 10 IV 1938, 9, 9, s. 3; idem, Jeszcze o instynkcie narodowym i Panu J.E. Skiwskim, „Polityka” 25 VI 1938, 9, 14 (159), s. 6; idem, O pogromach stów parę, "Słowo" 19 VI 1937, 16, 166 (4730), s. 1; idem, List do redakcji, „Polityka” 10 VI 1937, 8, 13 (127), s. 8; idem, Zygzakiem przez prase, „Bunt Młodych” 25 II 1937, 8, 5 (119), s. 6; idem, Śmiertelne niebezpieczeństwo żydowskie, „Polityka” 25 XI 1937, 8, 28 (142), s. 2. 
cy się społeczną wrażliwością, skłaniał się równocześnie w latach trzydziestych ku chrześcijańskiej myśli społecznej. Należałoby chyba uwypuklić związek tych poglądów z późniejszą postawą afirmacji pewnych aspektów powojennego systemu ekonomicznego. W obliczu wojny, publikując także na łamach „Polityki” Jerzego Giedroycia, Stomma wzywał do stawienia oporu Niemcom, snując jednocześnie dość mgliste koncepcje współpracy państw regionu (s. 69-70, 74-76). Znamienne, że nie dostrzegał ryzyka sowieckiej agresji w przypadku konfliktu polsko-niemieckiego. Trzeba też dodać, że teksty o wymowie antyniemieckiej na łamach następcy „Buntu Młodych" były wyrazem ogólnej reorientacji politycznej grupy „młodokonserwatystów" w przededniu wojny ${ }^{11}$. Wszak na łamach jej prasy w latach trzydziestych ukazywały się artykuły głoszące konieczność prewencyjnej agresji na Związek Sowiecki w politycznym przynajmniej przymierzu z Rzeszą Niemiecką. Stwierdzić należy, że Autor nie podjął się drobiazgowej analizy wszystkich artykułów swego bohatera. Nie jest to bynajmniej zarzut, a jedynie stwierdzenie faktu. Zastosowana metoda sprawia zreszta, że narracja nie jest nużąca, a główne nurty myśli politycznej Stommy, jak się wydaje, zostały zaprezentowane w wyczerpującym zakresie.

Lata wojny przyszły poseł spędził najpierw na Łotwie, potem na Wileńszczyźnie, a wreszcie w podwarszawskich Laskach. Znamienne, że angażując się w wileńską konspirację, wzywał (podobnie jak Leon Lech Beynar, znany potem jako Paweł Jasienica) do powstrzymania się od heroicznych, ale brawurowych i ryzykowanych oraz niepotrzebnych wyczynów (s. 79). Koncepcję operacji „Ostra Brama” uznał za absurdalną wobec planów zajęcia Wilna przez Armię Czerwoną, rezygnując z udziału w niej. Przybywając do Lasek w przededniu powstania warszawskiego, mógł obserwować z bliska tragedię stolicy. Napawała go ona przekonaniem o politycznej szkodliwości decyzji Komendy Głównej Armii Krajowej, chociaż oddawał równocześnie hołd walczącym, sam także w pewnym stopniu uczestnicząc w zrywie (s. 80-82). Poznany wówczas ksiądz Stefan Wyszyński przekonał go, że wobec wyniszczenia kraju i politycznej klęski sprawy polskiej ostoją idei, które były bliskie Stommie, może być jedynie Kościół katolicki. Jak słusznie zauważył Ptaszyński, skłoniło go to do zaangażowania w ruch katolików, szukających modus vivendi z komunistami (s. 83). Powyższe kwestie stanowią treść rozdziału pierwszego, wprowadzającego niejako do tytułowego zagadnienia "stommizmu”, związanego wszak z aktywnością bohatera książki w Polsce Ludowej.

11 Co cechowało także wileńskie "Słowo”. J. Sadkiewicz, „Ci, którzy przekonać nie umieja". Idee porozumienia polsko-niemieckiego w publicystyce Wtadysława Studnickiego i wileńskiego "Słowa" (do 1939), Kraków 2012, s. 229-286. 
Rozdział drugi dotyczy zasadniczej nie tylko dla myśli politycznej Stommy kwestii: maksymalizmu i minimalizmu w postawach katolików wobec Polski Ludowej. Lekki niedosyt budzi co prawda nakreślenie biografii politycznej i ideowej u schyłku wojny. Autor przedstawił wszystkie ważne informacje $\mathrm{w}$ tej kwestii, jednakże nie pokusił się o szersze interpretacje i osadzenie spraw w głębszym kontekście. Pisząc o zaangażowaniu swego bohatera w działalność Rady Głównej Opiekuńczej i jej Biura Studium Politycznego (s. 85-86), nie rozwinął wspomnianej przez siebie uwagi Andrzeja Friszkego o ciągłości koncepcji Adama Ronikiera i Aleksandra Bocheńskiego poszukiwania porozumienia z Niemcami a poglądami na możliwość zawarcia przez polską inteligencję katolicką kompromisu z Sowietami. Dodać należy, że samo Biuro także nie było jednolite w tych kwestiach - wydana przez nie broszura Józefa Mackiewicza Optymizm nie zastapi nam Polski zdecydowanie odrzucała jakiekolwiek próby ugody z Sowietami, głosząc hasło „lepsza Polska żadna niż czerwona" ${ }^{2}$. Kwerenda w zespołach RGO w Archiwum Akt Nowych pozwoliłaby także silniej potwierdzić źródłowo zatrudnienie Stommy w Radzie u schyłku wojny. Warto też nadmienić, że we wspomnianych przez Ptaszyńskiego, a zainicjowanych przez Bocheńskiego rozmowach grupy intelektualistów z Jerzym Borejszą brali też udział tacy przedstawiciele sfer konserwatywnych, jak Alfred Wielopolski (prawnuk Margrabiego) i Seweryn Dolański ${ }^{13}$. Wartościowe jest też opracowanie Ryszarda Mozgola dotyczące tych negocjacji, oparte m.in. na materiałach z Archiwum Katolickiego Stowarzyszenia Civitas Christiana ${ }^{14}$. Ciekawe byłoby większe zwrócenie uwagi na krótki pobyt Stommy w seminarium duchownym i rozwinięcie motywów decyzji o jego opuszczeniu.

Te drobne niedostatki rekompensuje dalsza część narracji rozdziału drugiego. Autor wnikliwie zanalizował zdefiniowanie przez Stommę kwestii minimalizmu i maksymalizmu, dowodząc, że tytułowy „stommizm" jest zjawiskiem w myśli politycznej autonomicznym wobec dwóch pojęć, które Stomma de facto wprowadził do katolickiej debaty intelektualnej swym głośnym esejem z 1946 r. ${ }^{15}$ Publicysta odniósł się w ten sposób

12 J. Mackiewicz, Optymizm nie zastapi nam Polski, Londyn 2013.

13 A. Garlicki, Z tajnych archiwó́w, Warszawa 1993, s. 25, 27.

14 R. Mozgol, Ryzykowna gra. Jak Aleksander Bocheński przyczynit się do powstania Dziś i Jutro, „Biuletyn Instytutu Pamięci Narodowej” 2007, 4 (75), s. 84-92; Archiwum Katolickiego Stowarzyszenia Civitas Christiana w Warszawie, Zespół akt dotyczących Aleksandra Bocheńskiego, sygn. VII A-305, „Jak doszło do powstania «Dziś i Jutro». Dyskusja na łamach «Życia i Myśli» nr II 21975 z udziałem: Aleksander Bocheński, Jan Dobraczyński, Jerzy Hagmajer, Mieczysław Kurzyna, Romuald Szpor" [wersja robocza maszynopisu, tekst nigdy nieopublikowany na łamach prasy Stowarzyszenia „PAX”].

15 S. Stomma, Maksymalne i minimalne tendencje społeczne katolików w Polsce, "Znak" wrzesień-grudzień 1946, 1, 3, s. 257-275. 
do sporu nie tylko o postawy katolików wobec rzeczywistości powojennej, ale też o definicje i granice realizmu politycznego, opowiadając się za uznaniem obiektywnych uwarunkowań, stawiając jednak wyraźną granicę kompromisu (co Ptaszyński wyeksponował zwłaszcza na s. 126-127, 135-136, 139-140, a także przy analizie stosunku Stommy do sytuacji politycznej z lat 1953-1956). Na marginesie tych rozważań nasuwają się dwie uwagi. Pierwsza dotyczy braku odwołania się do istotnych dla refleksji nad polską myślą polityczną ustaleń Piotra Kimli dotyczących nie tylko definicyjnych aspektów realizmu politycznego, ale też jego relacji ze zjawiskiem etyki w polityce ${ }^{16}$, czy też rozważań Hansa Joachima Morgenthaua nad tą tematyką ${ }^{17}$. Druga dotyczy kwestii kontekstu: być może warto byłoby osadzić spór o minimalizm i maksymalizm na tle ówczesnych debat o granice realizmu? Toczone były one wszak na marginesie Dziejów głupoty $w$ Polsce A. Bocheńskiego i Margrabiego Wielopolskiego Ksawerego Pruszyńskiego, także na łamach prasy katolickiej ${ }^{18}$. Autor co prawda odwołuje się do dotyczących zagadnienia kultu męstwa żołnierskiego artykułów Hanny Malewskiej (s. 105), ale nie wspomina, że były one głosem w „dyskusji nad Monte Cassino", którą prowadzono na łamach „Tygodnika Powszechnego", a która dotyczyła sensu poświęcenia żołnierskiego właśnie ${ }^{19}$. Wysoko ocenić należy refleksje Ptaszyńskiego o poglądach

16 P. Kimla, Historycy-politycy jako źródło realizmu politycznego. Tukidydes - Polibiusz Machiavelli, Kraków 2009; idem, Etyka w realizmie politycznym, „Czasopismo Prawno-Historyczne" 2014, 66, 2, s. 303-314; idem, Realistyczne krytyki moralizatorstwa w polityce, w: Moralność i władza jako kategorie myśli politycznej, red. J. Justyński, A. Madeja, Warszawa 2011, s. 13-22; P. Kimla, Realizm polityczny a Polska, w: Między sercem a rozumem. Romantyzm i realizm w polskiej myśli politycznej, red. A. Citkowska-Kimla, P. Kimla, E. Antipow, K. Konik, Kraków 2017.

17 H.J. Morgenthau, Polityka między narodami. Walka o potęge i pokój, Warszawa 2010.

18 J. Braun, Bronię romantyzmu, „Tygodnik Warszawski” 15 II 1948, 4, 7 (116), s. 1; idem, Katolicyzm a machiawelizm, „Tygodnik Warszawski” 21 III 1948, 4, 12 (21), s. 1, 6; I. Pannenkowa, Mentorzy, „Tygodnik Warszawski” 7 II 1947, 3, 49 (108), s. 3-4; S. Kieniewicz, Nowy sąd nad historia, „Dziś i Jutro” 22 VI 1947, 3, 25 (82), s. 1-2; S.K. Rostworowski, O szkołę politycznego myślenia, „Dziś i Jutro” 13 VII 1947, 3, 28 (85), s. 3-4; J. Meysztowicz, Jeszcze "Dzieje głupoty”, „Dziś i Jutro" 10 VIII 1947, 3, 22 (89), s. 12.

19 A. Bocheński, O dyskusji nad Monte Cassino, „Tygodnik Powszechny” 10 XI 1946, 2, 45 (86), s. 1; P. Jasienica, Polityczna waga heroizmu, "Tygodnik Powszechny" 17 XI 1946, 2, 46 (87), s. 12; T. Cyprian, J. Sawicki, Polityka zagraniczna dwudziestolecia, „Tygodnik Powszechny" 8 XII 1946, 2, 49 (90), s. 7; W. Kirchmayer, Bohaterstwo i rozdział kompetencji, „Tygodnik Powszechny" 8 XII 1946, 2, 49 (90), s. 7-8; ks. M. Lewicki, Co jest prawda, a co chimera, „Tygodnik Powszechny" 16 II 1947, 3, 7 (100), s. 6; M.W. Lis, O realizmie i polityce, "Tygodnik Powszechny" 16 II 1947, 3, 7 (100), s. 7-8; H. Malewska, Realizm?, „Tygodnik Powszechny" 8 XII 1946, 2, 49 (90), s. 6; A. S., Spór o idee, „Tygodnik Powszechny” 16 II 1947, 3 , 7 (100), s. 8; M. Straszewski, Błędy polityki przedwrześniowej, „Tygodnik Powszechny” 8 XII 1946, 2, 49 (90), s. 7; K. Syrewicz, Problem źle postawiony, "Tygodnik Powszechny" 8 XII 1946, 2, 49 (90), s. 7; 
prawniczych Stommy osadzone w kontekście jego koncepcji politycznych (s. 93-94) oraz podkreślanie przez Autora stosunku Stommy do B. Piaseckiego, a także ideologii „Dziś i Jutro” (coraz bardziej sceptycznego, ale otwartego na pewien kompromis). Podnieść muszę natomiast zastrzeżenie wobec przypisywania dawnemu wodzowi „Falangi” diabolicznych jedynie koncepcji wobec rodzącego się środowiska "Znaku” (s. 112). Jak się wydaje, Piasecki w swej utopijnej wizji „przezwyciężenia zwycięzcy” 20 szukał w Jerzym Turowiczu i Stommie sojuszników, których co prawda chciał sobie podporządkować, ale nie całkowicie wchłonąć. $Z$ pewnością zaś nie chciał tego środowiska w złej intencji niszczyć. Cenne i prowokujące do refleksji są także uwagi o wpływie powojennej społecznej atomizacji i rozczarowania wynikami wojny na postawy zaangażowania politycznego katolików (s. 99). Interesujące jest nakreślenie stanowiska Stommy wobec koncepcji powołania stronnictwa katolickiego w latach 1946-1947, także w kontekście sporu o minimalizm i maksymalizm w samej kurii krakowskiej (s. 100-104).

$\mathrm{Na}$ wysoką ocenę zasługują również refleksje o postawie politycznej Stommy w latach 1953-1956 będącej wyrazem niełatwych przecież do rozwiązania dylematów katolika świeckiego, dotyczących granic realizmu i idealizmu w warunkach zdecydowanej walki państwa z Kościołem katolickim. Stanisław Stomma, jak dowiódł Radosław Ptaszyński, posiadał własną koncepcję, której blisko było do non possumus prymasa, ale która nie odrzucała możliwości kompromisu nienaruszającego imponderabiliów. Dlatego też z pewnym entuzjazmem odnosił się do przemian październikowych, co kontrastowało z bardziej sceptyczną postawą Stefana Wyszyńskiego. Publicysta był jednak niechętny odważnym koncepcjom tworzenia partii katolickiej, uznając je za zbyt daleko idące (s. 165-166). Jako jeden z twórców Klubów Inteligencji Katolickiej cechował się uznaniem pryncypiów geopolitycznych i ustrojowych Polski Ludowej, opierając się na realizmie wywiedzionym nie tylko z obserwacji bieżących uwarunkowań, ale także wzorców historycznych. Wyrazem tego był, jak słusznie zauważa Autor, artykuł Dostęp do Polski współczesnej, zamieszczo-

F. Wydra, Głos żotnierza, „Tygodnik Powszechny” 16 II 1947, 3, 7 (100), s. 8; I. Pannenkowa, Realizm, bohaterstwo - i bomba atomowa, "Tygodnik Warszawski" 11 V 1947, 3, 19 (78), s. 3-4; A. Bocheński, Odpowiadam oponentom, „Tygodnik Powszechny” 16 II 1947, 3, 7 (100), s. 6.

20 B. Bankowicz, W labiryncie wieloświatopogladowości: Stowarzyszenie PAX między realizmem a rzeczywistościa, w: eadem, A. Dudek, Ze studiów nad dziejami Kościoła i katolicyzmu w PRL, Kraków 1996, s. 53-71; eadem, Stowarzyszenie PAX: między rzeczywistościa socjalizmu realnego a utopia socjalizmu wieloświatopogladowego, w: Doktryny. Historia. Władza. Księga dedykowana profesorowi Wiesławowi Kozubowi-Cembroniewiczowi z okazji czterdziestolecia pracy naukowej, red. A. Citkowska-Kimla, M. Kawior-Filo, B. Szlachta, Kraków 2009, s. 37-48. 
ny na łamach „Przeglądu Kulturalnego"21 (s. 170-171). Ze swej strony pragnę dodać, że wzbudził on krytykę Ireny Pannenkowej, która (podobnie jak w latach czterdziestych ubiegłego stulecia) postponowała próby łączenia postawy afirmacji Polski Ludowej z koncepcjami realistycznymi i neopozytywistycznymi. Znamienne zreszta, że Stomma w tym tekście bardzo pochlebnie pisał o Dziejach głupoty w Polsce Aleksandra Bocheńskiego, które znana pamflecistka surowo oceniała już w latach czterdziestych ${ }^{22}$.

Lata 1957-1961, stanowiące cezury kolejnego rozdziału, Ptaszyński określił jako czas dominacji w biografii Stommy neopozytywizmu, zaznaczając, że dotyczył on bardziej praktyki działania niż teoretycznych rozważań. Niemniej jednak Autor nie ucieka także od zagadnień związanych z teorią myśli politycznej, wskazując na najważniejsze, programowe enuncjacje swego bohatera. Dzięki temu i umiejscowieniu ich w odpowiednim kontekście (przede wszystkim związanym z fluktuacją napięcia na linii państwo-Kościół) można dojść do wniosku o znamiennej ewolucji politycznego realizmu bohatera książki. O ile bowiem zawsze pozostawał on wierny analizie wyciąganej z trzeźwej oceny uwarunkowań przy trosce o pewne imponderabilia, zmieniały się jego poglądy na temat form zaangażowania politycznego katolików. Przestrzeń między minimalizmem i maksymalizmem Stomma wypełniał własną koncepcją. Minimalizm był zatem dla niego w Polsce Władysława Gomułki rozwiązaniem ostatecznym, ale możliwym, maksymalizm zaś w jego rozważaniach nigdy nie wchodził w rachubę. Odrzucał jednak także oportunizm, za którego przedstawicieli uznawał B. Piaseckiego i J. Frankowskiego. Tym bardziej szkoda, że, podobnie jak w poprzednich rozdziałach, Autor nie oparł swych rozważań na naukowej refleksji nad politycznym realizmem. Niemniej jednak szczegółowo scharakteryzował także w tej części, jak Stomma rozumiał granice kompromisu (s. 220-221) i znaczenie etyki w polityce (s. 226-227). Ugodowość bohatera książki wzbudzała zresztą pewne kontrowersje w jego środowisku - sam J. Turowicz (podobnie jak Autor książki) za zbyt daleko posunięty uznawał pogląd, że „Znak” powinien być politycznym sojusznikiem Gomułki.

W kwestiach merytorycznych trudno tej części pracy cokolwiek zarzucić. Autor poruszył tak istotne kwestie, jak relacje Stommy z Prymasem, wskazując na przyczyny różnic zdań pomiędzy nimi (s. 190-191, 209210), próbę zabiegów o powołanie dziennika katolickiego pod kierunkiem

21 S. Stomma, Dostęp do Polski wspótczesnej, „Przegląd Kulturalny” 25 X-21 X 1956, 5, 43 (217), s. 6-7.

22 I. Pannekowa, Historia mistrzynia życia ale tylko prawdziwa. O racji stanu, ideologii, oraz mądrości i głupocie politycznej, „Przegląd Kulturalny” 21 III-27 III 1957, 6, 12 (238), s. 1, 8-9. Por. eadem, Czy nie za wiele pesymizmu?, „Tygodnik Warszawski” 25 VIII 1946, 2, 34 (41), s. 2. 
„Znaku” i grupy J. Frankowskiego (s. 194-195), początek sporu z J. Zabłockim i pewne kontrowersje w relacjach grupy krakowskiej w "Więzi" (s. 231, 242, 245-250), aspekty działalności koła poselskiego „Znak”, relacje grupy z W. Gomułką. Być może zbyt skąpo zostały scharakteryzowane ekonomiczne rozważania polityków i publicystów "Znaku” (chociaż Ptaszyński zauważył, że na sprawach ekonomicznych Stomma bliżej się nie znał: s. 243-245). Nie zaszkodziłoby też krótkie omówienie relacji środowiska z grupą J. Frankowskiego (Chrześcijańskie Stowarzyszenie Społeczne). Przy wspomnieniu o „PAX-owskim” epizodzie K. Łubieńskiego, który był przyczyną pewnej nieufności Stommy do niego, dodać też należałoby informację o jego epizodzie w środowisku "Za i przeciw".

Lata sześćdziesiąte były czasem narastającego konfliktu na linii państwo-Kościół. Stawiało to nowe wyzwania nie tylko przed prymasem, ale także przed ruchem „Znak”. Podkreślić należy, że nie był on bynajmniej reprezentantem politycznej linii Wyszyńskiego i jego „parlamentarno-dziennikarskim" ramieniem, lecz samodzielnym bytem politycznym, wewnętrznie zresztą zróżnicowanym. Radosław Ptaszyński trafnie zróżnicował spór, jaki wówczas stawał się coraz bardziej widoczny między "Znakiem” i Stanisławem Stommą osobiście a Stefanem Wyszyńskim. O ile prymas był rzecznikiem współpracy z komunistami jedynie w kwestiach zasadniczych (takich jak: granica zachodnia, stabilizacja wewnętrzna, zapobieżenie sowieckiej interwencji), będąc zdecydowany bezkompromisowo walczyć o prawa Kościoła, o tyle Stomma politykę taką uważał za błędną i wywołującą niepotrzebny konflikt. Ponadto, prymas Wyszyński pragnął opierać się na katolicyzmie ludowym, zaś "Znak" bliski był personalizmowi, krytykującemu bezrefleksyjnie przeżywaną religijność (s. 277-278, 286-287). Co prawda w kwestii II Soboru Watykańskiego Stommie było bliżej do prymasa niż do J. Turowicza (co nie oznaczało podzielania poglądów), ale już słynna „opinia rzymska” nieuzgodniona z S. Wyszyńskim była sporem nie tyle może o idee, co o metody działania. Także w kwestii stosunku do przeszłości realista Stomma różnił się w sposób zasadniczy od głowy Kościoła w Polsce. Jego artykuł opublikowany w setną rocznicę powstania styczniowego, będący krytyką decyzji o rozpoczęciu walki z Rosją i apologią polityki margrabiego Aleksandra Wielopolskiego, wywołał oburzenie Stefana Wyszyńskiego. Jest to zresztą kolejny przyczynek do „stommizmu”, czyli koncepcji realizmu politycznego bohatera książki. Ciekawe, że krytykując zryw 1863 r., Stomma potępiał równocześnie próby szukania porozumienia z okupantami w latach II wojny światowej. Całokształt postawy polityka wywoływał negatywne reakcje działaczy "Znaku” i intelektualistów, chociażby Władysława Bartoszewskiego. Niemniej jednak Stomma daleki był od ugodo- 
wości „PAX-u”. Dość stwierdzić, że zdecydowanie krytykował wsparcie B. Piaseckiego dla koncepcji „,socjalistycznej przebudowy wsi” i usunięcia lekcji religii ze szkół (s. 255-256 ${ }^{23}$. Wszystkie te kwestie zostały poruszone w rozdziale dotyczącym lat 1961-1967.

Wzrost natężenia walk frakcyjnych w PZPR przełożył się na rozbieżności w ruchu "Znak”. Zagadnienie to jest jednym z głównych przedmiotów rozważań $\mathrm{w}$ kolejnym rozdziale, poruszającym problematykę działalności Stommy w latach 1968-1976. Ich główną osią był rzecz jasna konflikt między Stommą a J. Zabłockim. Ten ostatni coraz mocniej zbliżał się do "partyzantów”, głosząc hasła nacjonalistyczne i starając się schlebiać (nieczułemu na jego zabiegi) prymasowi. Oskarżając Stommę o kosmopolityzm, twórca Ośrodka Dokumentacji i Studiów Społecznych grawitował ku „marcowej” propagandzie. O ile wiosną 1968 r. czuł się jeszcze w obowiązku poprzeć swoje koło poselskie w sprawie interpelacji biorącej w obronę represjonowanych studentów, o tyle wkrótce potem nie ukrywał już nawet swego krytycyzmu wobec linii politycznej, jaką prezentował przewodniczący koła. Należy podkreślić, że mógł w tym liczyć także na publicystów "Za i przeciw”. Zbliżało to równocześnie Stommę do Wyszyńskiego, któremu imponowała postawa "Znaku” w dobie wydarzeń $1968 \mathrm{r}$.

Kwestie te stanowią treść kolejnego rozdziału książki. Autor umieścił swoje rozważania na wyjątkowym, obszernym tle, ukazując nie tylko działalność Stommy, ale też koncepcje prymasa oraz działaczy „Znaku”. Sprawy te, jak słusznie zauważa Autor, były kolejnym etapem lawirowania publicysty między minimalizmem i maksymalizmem. Rok 1968 naruszył, zdaniem Stommy, granice tolerowanego kompromisu. Stąd też uznawał on, że wyjściem było albo rozwiązanie koła poselskiego, albo jasne opowiedzenie się za Wyszyńskim. Do jednego ani do drugiego z rozmaitych przyczyn jednak nie doszło, co on sam traktował jako przyczynę rozpadu ruchu. Istotnie, oprócz sporu z J. Zabłockim widoczny stawał się także, łagodny na razie, antagonizm $\mathrm{z} \mathrm{K}$. Łubieńskim, optującym w kierunku afirmacji socjalistycznego systemu ekonomicznego. Obaj w ten sposób ponownie starali się zbliżyć ideowo do „PAX-u”, z którego się wywodzili (konstatacji tej zabrakło w książce).

Wartościowe są także refleksje Autora o krytycznym stosunku Stommy do płytkości polskiego ludowego katolicyzmu (s. 378-380) oraz łączeniu koncepcji antyinsurekcyjnych z wywiedzioną z A. Wielopolskiego apo-

${ }^{23}$ Por. Archiwum Instytutu Pamięci Narodowej w Warszawie, sygn. IPN BU 01210/156, „Informacja dot.: sytuacji w Stowarzyszeniu «Pax», Warszawa, dnia 27 października 1959 r.”, k. 142-143; sygn. IPN BU 0648/56/1, „Notatka służbowa z dnia 13.VII.61 r.”, k. 28. 
logią współpracy polsko-rosyjskiej. Dodałbym przy tym ostatnim zagadnieniu wniosek o nierozróżnianiu przez Stommę krytyki błędnych decyzji i kultu męstwa żołnierskiego. Ten ostatni, w przypadku błędnych powstań uznawał za niewychowawczy, gdyż utrwalający mniemanie o słuszności decyzji wiodących naród do zguby ${ }^{24}$. Znamienne jest też, że Stomma również później, już w dobie odczuwalnego fiaska koncepcji „Znaku” jako czynnika niezależnego i rodzącej się opozycji demokratycznej, przestrzegał przed koncepcjami antyrosyjskimi i insurekcyjnymi.

Należy podkreślić, że bohater książki Radosława Ptaszyńskiego nie był dogmatykiem. Zdawał sobie sprawę, że będąca wyznacznikiem politycznego realizmu „mądrość etapu” nie może prowadzić do oportunizmu. Ryzyko takie wiązałoby się z pewnością z brakiem kontrakcji wobec działalności Janusza Zabłockiego, Konstantego Łubieńskiego i Wacława Auleytnera, którzy „Znak” spychali na pozycje wasala PZPR w aspekcie ideologicznym. Trzeba też dodać, że zabiegom tym sprzyjała poprawa relacji państwo-Kościół. Stanisław Stomma wolał wycofać się z działalności ruchu niż firmować swoim nazwiskiem działania, z którymi głęboko się nie zgadzał. Polityka realna, jak słusznie zauważał Ptaszyński (s. 505-507) była dla myśliciela umiejętnością wyzyskania okoliczności przy wierności imponderabiliom. Jeśli okoliczności były niesprzyjające, alternatywą był minimalizm, będący obroną dotychczasowych zdobyczy. Co jednak, jeśli także tych ostatnich nie udawało się zachować? Wówczas, według koncepcji "stommizmu” potrzebny był gest maksymalistyczny, lecz przemyślany. Było nim oczywiście wstrzymanie się od głosu przy głosowaniu nad zmianą Konstytucji PRL w lutym 1976 r. Radosław Ptaszyński (co prawda trochę zbyt oględnie) stwierdza, powtarzając argumentację Stommy, że głosowanie przeciw byłoby nieefektywnym igraniem z przeciwnikiem. Neopozytywizm Stommy nabrał w ten sposób oblicza niemalże „rejtanowskiego”, chociaż, co znamienne, polityk nie wykluczał możliwości kontynuowania pracy poselskiej. Omówienie przez Autora genezy i konsekwencji decyzji posła należy ocenić jak najbardziej pozytywnie. Warty podkreślenia jest też fakt, że szef koła "Znak” zmienił w tym czasie swój stosunek do koncepcji prymasa, uznając wagę odwoływania się do „katolicyzmu ludowego" i wizję Wyszyńskiego jako „interrexa”.

Schyłek lat siedemdziesiątych i lata osiemdziesiąte nie oznaczały jednak rezygnacji Stommy z zainteresowania sprawami publicznymi. Ruch „Znak" (rozumiany jako środowisko niezależne od władz) nie posiadał już reprezentacji w parlamencie. Odejście grupy Zabłockiego i Łubieńskiego

24 Por. A. Bocheński, Rozmyślania krytyczne. Błąd Zbigniewa Florczaka, „Kierunki” $27 \mathrm{~V}$ 1956, 1, 2, s. 1. 
nie przyczyniło się do zakończenia sporów, jednak dotyczyły one przede wszystkim stosunku do rodzącej się opozycji. Problem ten uwidaczniał także permanentną kompromisowość i ostrożność Stommy. Z pewnością odszedł on od koncepcji neopozytywizmu (jak zauważa Autor: s. 563), co jednakże nie oznaczało jego przejścia na pozycje maksymalistów. Nie zaangażował się w działalność ruchu związkowego, pełniąc raczej funkcję życzliwego obserwatora. Chociaż uznawał Sierpień '80 za pierwszą polską zwycięską „rewolucję narodową”, to równocześnie obawiał się żywiołowości ruchu i braku wyrobienia politycznego przywódców. Radosław Ptaszyński poprawnie usytuował te dylematy na osi minimalizm-maksymalizm. Otwarte jednak pozostaje pytanie, w jakim stopniu obawy Stommy były tożsame z politycznym realizmem? Był on pewny nieuchronności wprowadzenia stanu wojennego, do którego wiodła nie tylko nieustępliwość władzy, ale i radykalizm opozycji. Zresztą przynajmniej do 1988 r. był przekonany, że bliska współpraca Polski z Moskwą jest wymogiem narodowej racji stanu. Odnieść można wrażenie, że inicjatywy bohatera książki, podejmowane czy to w ramach Prymasowskiej Rady Społecznej, czy Klubu Myśli Politycznej „,Dziekania”, były nierealne ze względu na to, że rządzący traktowali je jako zbyt liberalne, a opozycjoniści jako zbyt ugodowe. Niemniej jednak koncepcje Stommy należałoby rozpatrzyć nie z perspektywy wiedzy o przełomie 1989 r., ale próbując uwzględnić jego znajomość uwarunkowań. Czy udało się to Ptaszyńskiemu? Autor zaznacza, że Stomma był neopozytywista, ale daleko mu było do współpracy z ekipą Jaruzelskiego wspomnieć wystarczy, że odmawiał jakichkolwiek kontaktów z Patriotycznym Ruchem Odrodzenia Narodowego (s. 585, 599). Autor przedstawił też szeroko działalność swego bohatera, rekonstruując mozolnie jego koncepcje z lat osiemdziesiątych. Jak się wydaje, zabrakło jednak próby rekapitulacji i oceny owych zapatrywań oraz zanalizowania ich w kontekście politycznego realizmu. Dopowiedzieć zatem można, że Stomma, jako polityczny realista, nie przewidział rzecz jasna upadku systemu komunistycznego w Polsce, nie wspominając już o rozpadzie ZSRR. Trudno jednak czynić mu z tego zarzut - wszak wiele innych wybitnych intelektualistów i polityków uznawało taki scenariusz za nierealny. Ponadto, z czasem zaczął wysuwać śmielsze koncepcje: kooptacji części opozycji i katolickich intelektualistów do obozu władzy, jednakże za cenę liberalizacji systemu. Zapytać należy: cóż pozostawało osobie pragnącej trzeźwo rozpatrywać politykę, obserwującej impas w relacjach między władzą a opozycją czy szerzej - społeczeństwem? Stanisław Stomma wybrał próbę budowania kompromisu, co należy ocenić za zgodne z wyznacznikami politycznego realizmu, który stara się osiągnąć to, co możliwe, nie rezygnując z wierności nadrzędnym wartościom. Tymi zaś dla byłego posła pozostawały interes Polski rozumia- 
ny jako stabilizacja wewnętrzna i bezpieczeństwo międzynarodowe oraz zabezpieczenie praw Kościoła. Na marginesie - szkoda, że Autor nie przyjrzał się innym postaciom, które, pozostając w nurcie politycznego realizmu, wyrażały przekonanie o trwałości układu pojałtańskiego ${ }^{25}$.

Nie dziwi zatem, że Stomma bronił porozumień Okrąłego Stołu, widząc w nich wyraz rozsądnego kompromisu. Z podobnych względów uważał za konieczny wybór Wojciecha Jaruzelskiego na Urząd Prezydenta PRL - uznawał, że krok ten zapobiegnie politycznej destabilizacji kraju. Jego ocena Polski Ludowej także była wyważona i skierowana w kierunku obiektywizmu. Zrozumiałe jest jego rozczarowanie polskim parlamentaryzmem po 1989 r., który zdawał się powtarzać wszystkie błędy przeszłości. Stąd też opcją polityczną Stommy, mimo pewnych deklaracji o bliskości prawicy, były centrum i umiar. Znamienne jest, że łączył on konserwatywne poszanowanie dla tradycji i sprzeciw wobec modelu narodowo-ludowego z wrażliwością społeczna, ale także poparciem dla reform Leszka Balcerowicza. Oburzeniem napawały go próby wykorzystywania lustracji do walki politycznej, zaś jego marzeniem w polityce wewnętrznej były silna władza wykonawcza i zaniechanie sporów o przeszłość oraz troska o osoby poszkodowane kosztami transformacji. Stanisław Stomma sugerował bliskość takich poglądów z piłsudczykami. Trudno jednak zgodzić się z tą konstatacją i szkoda, że Autor nie poddał jej szerszej refleksji. Jeśli bowiem bohater książki był bliski piłsudczykom w swych poglądach w III $\mathrm{RP}$, to tym wywodzącym się z kręgów zachowawczych, zarówno „starych", jak i „młodych" konserwatystów (z tymi ostatnimi był wszak przed 1939 r. związany). Ciekawe, że polityk uznawał, iż zadaniem jego partii - Unii Wolności - było nie tyle dążenie do władzy, co oddziaływanie na politykę, czego, jego zdaniem, można było dokonać także w opozycji. Stosunek Stommy do relacji państwo-Kościół również był pełen umiaru. Bohater książki Ptaszyńskiego zdawał sobie sprawę, że po 1989 r. Episkopat, ale też laikat, nie będą w stanie odgrywać takiej roli, jak w Polsce Ludowej, gdzie Kościół był depozytariuszem imponderabiliów.

Niezwykle interesujące i warte zaakcentowania są koncepcje Stommy dotyczące polskiej polityki zagranicznej po 1989 r. Autor co prawda nie zaznaczył wyraźnie odejścia swego bohatera od koncepcji prorosyjskiej do proniemieckiej, uwidocznił jednak oryginalność jego refleksji geopolitycznej oraz przenikliwość pewnych wizji. Sędziwy polityk był rzecznikiem

${ }^{25}$ Jednym $\mathrm{z}$ najciekawszych przykładów takiej postawy był Aleksander Bocheński. A. Orzełek, Aleksander Bocheński wobec działalności i koncepcji Patriotycznego Ruchu Odrodzenia Narodowego, „Dzieje Najnowsze” 2018, 50, 1, s. 263-279; idem, Publicystyka Aleksandra Bocheńskiego wobec stanu wojennego w Polsce. Dylematy realizmu PAX-owca, w: Letnia Szkoła Historii Najnowszej 2015. Referaty, red. Ł. Kamiński, J. Szumski, Warszawa 2016, s. 103-115. 
integracji Polski ze strukturami euroatlantyckimi (naiwnie pisząc zreszta, że USA nigdy nie atakowały państw we własnym interesie, zaś zawsze spieszyły z pomocą pokrzywdzonym: s. 649). Sprawę tę rozpatrywał jednak przede wszystkim $\mathrm{w}$ kontekście relacji niemiecko-rosyjskich. Powtarzał w ten sposób tezę Romana Dmowskiego, Władysława Studnickiego, Stanisława Cata-Mackiewicza czy braci Adolfa i Aleksandra Bocheńskich o tym, że polska polityka zagraniczna dążyć powinna przede wszystkim do zapobieżenia zbliżeniu Berlina i Moskwy. Uznawał zatem, że alternatywą dla integracji z NATO i Unią Europejska, prowadzącą do bliskich relacji z Niemcami, jest antypolski pakt dwóch potężnych sąsiadów i „nowa okupacja” (s. 648-649). Jako błędne traktował też koncepcje „Międzymorza”, nazywając je drogą do „Rapallo”. Twierdził bowiem, że potencjał państw regionu środkowoeuropejskiego nie jest w stanie zrównoważyć siły ewentualnej koalicji Niemiec i Rosji. Tę zaś uznawał za pewną wobec prób budowania takiego porozumienia (s. 649-650). Różnił się w tym znacząco od czołowych umysłów polskiej emigracji - Jerzego Giedroycia i Jana Nowaka-Jeziorańskiego, ale także, co oczywiste, od tradycji piłsudczykowskiej myśli politycznej. Jak się wydaje, wpływ na to miała nie tylko trzeźwa analiza geopolityki, lecz także doświadczenia powojenne. Rosję uznawał w latach dziewięćdziesiątych za państwo przeżywające jedynie chwilowe problemy. O ile nie wchodziła ona jednak w spory terytorialne z Polską, państwo rewizjonistyczne mogły z niej uczynić próby pchnięcia Ukrainy i Białorusi na drogę wyzwolenia się spod wpływów Moskwy. Politykę tę, która wszak była (i jest) dogmatem polskiej dyplomacji po 1989 r., uznawał za samobójczą. Przewidział, że zwrot Ukrainy w kierunku euroatlantyckim musi spowodować konflikt na wschodzie tego państwa (s. 650-654). W swych poglądach był osamotniony, co zresztą nie stanowi o jakichkolwiek negatywnych ich aspektach. Polityk w tych właśnie kwestiach odszedł od Józefa Piłsudskiego najdalej, zbliżając się do wykładni polskiej geopolityki w ujęciu Romana Dmowskiego.

W kontekście politycznego realizmu Autor rozpatrzył też stosunek publicysty do skomplikowanego problemu powojennych relacji polsko-niemieckich, czyniąc je przedmiotem osobnej części książki. Radosław Ptaszyński trafnie dostrzegł, że w swym dążeniu do unormowania stosunków Polski ze wschodnim sąsiadem jego bohater kierował się nie sentymentalizmem, lecz nakazami geopolityki. Uznając bowiem istnienie granicy na Odrze i Nysie za wymóg narodowej racji stanu, dostrzegał równocześnie groźbę prób jej rewizji. Wyzyskując zatem wszelkie atuty stojące po polskiej stronie („,sojusz" z Moskwą, podział Niemiec, pamięć o polskich ofiarach wojny), na miarę swych kompetencji dążył do uznania linii granicznej przez RFN. Praca Stommy w tym kierunku miała charak- 
ter przede wszystkim opiniotwórczy, co też wynikało z jego ograniczonych możliwości. Symptomatyczne jest, że sam opierając się na politycznym realizmie, umiał wyzyskać niemieckie poczucie winy, a więc czynnik irracjonalny, dla realizacji polskiej racji stanu.

Mocną stroną książki jest analiza nie tylko kwestii politycznych, ale także uwaga, jaką Autor poświęca życiu prywatnemu swego bohatera. Dzięki temu postać Stommy jawi się jako polityk, publicysta, ale też człowiek targany, o czym często zapominają historycy, zwykłymi ludzkimi namiętnościami. Wielką zaletą pracy jest jej styl - lekki i swobodny, a także niepozbawiony humoru i ironii (np. s. 129-130), również przy charakteryzowaniu kwestii dotyczących skomplikowanych zagadnień z zakresu organizacji i myśli politycznej katolików świeckich w Polsce Ludowej. Autor wykazał się przy tym wielką wrażliwością i empatią przy analizowaniu przypadków „łamania” przez organy bezpieczeństwa Polski Ludowej duchownych i katolików świeckich (s. 133-135), równocześnie skrupulatnie przedstawiając kwestię prób sterowania ruchem „Znak” przez MSW. Uznał jednak przy tym, że pełna odpowiedź na pytanie o stopień wpływu organów bezpieczeństwa Polski Ludowej na rozłam w "Znaku” jest źródłowo nieuchwytna. Docenić też należy, że mimo swojej sympatii do Stommy wykazał się empatią wobec jego największego przeciwnika wewnątrz nurtu katolików świeckich - J. Zabłockiego. Dowiódł, że kierował się on przede wszystkim ambicją i wolą realizacji własnych koncepcji.

Autor nie ustrzegł się drobnych błędów. Józef Piłsudski nie posiadał, podczas wyprawy na Wilno, stopnia marszałka Polski (s. 30). Oczywiście u schyłku lat czterdziestych Stomma nie mógł zbliżać się do pięćdziesiątego roku życia (s. 90), ale do czterdziestego.

Czym zatem był „stommizm”? Nie tylko poszukiwaniem przestrzeni między minimalizmem i maksymalizmem, ale też próbą konstruowania modelu realizmu politycznego zależnego od konkretnych uwarunkowań. Cechowała te dążenia "mądrość etapu”, próba poszukiwania pozytywów w każdej sytuacji, a przez to - możliwości ich wyzyskania. Stanisław Stomma nie marnował żadnej okazji do działania politycznego, jeśli nie naruszało ono imponderabiliów (znamienne jest, że z ochotą szedł na rozmowę z Julią Brystygierową, licząc na możliwość wytargowania od niej pewnych koncesji politycznych: s. 137). Działanie polityczne nie mogło, jego zdaniem, być prowadzone w poprzek nurtu wydarzeń. Polityka nie była dla Stommy fantazją, idealizmem, opierającym się na zasadzie „wszystko albo nic”. Publicysta wolał szukać „mniejszego zła", także dla dobrego współczesnego mu pokolenia, niż ryzykować jego stan posiadania dla hipotetycznych, mało realnych korzyści. Dlatego też uważał, że ci, którzy bronią zdobyczy Października są o wiele lep- 
szymi politykami od romantyków, którzy byt narodu ryzykowali w imię mglistych koncepcji (jak gen. Tadeusz Bór-Komorowski). Konflikt polityczny można było, zdaniem Stommy, przyjąć tylko wówczas, gdy był nieunikniony i dotyczył kwestii zasadniczych. Decydowanie polityczne okazywało się w tym kontekście wolnym wyborem, ale opartym na racjonalnych determinantach. Wszelkie sztywne deklaracje były wobec tego nie tylko zbędne, ale nawet szkodliwe. Stąd też, przy całej swojej sympatii do państw zachodnich, Stomma krytykował jakąkolwiek wiarę w ich realną pomoc dla Polski. Był nie tylko „upartym”, ale i twardym Litwinem. Jerzy Zawieyski, jeden z liderów "Znaku”, płakał po ostrej rozmowie z Gomułka, tymczasem na Stommie takie starcia nie robiły większego wrażenia. Znamienne jest też, że cechowała go większa doza empatii wobec ideowych przeciwników, takich jak Władysław Gomułka czy Zenon Kliszko (tego ostatniego darzył nawet pewna, odwzajemniana, sympatią), niż wobec oponentów wewnątrz własnego nurtu (prymasa Wyszyńskiego, J. Zabłockiego).

Stomma, jak podkreśla Autor, był politycznym realistą i jednym z twórców wykładni tego stylu politycznego myślenia w polskiej myśli politycznej. Co równie istotne i wielce znamienne zapamiętany został przede wszystkim z gestu romantycznego, „rejtanowskiego”. Zasadne jest zatem pytanie, czy, nieuwzględniająca w zasadzie dorobku „stommizmu”, polska debata publiczna jest na skutek tego uboższa?

W mym przekonaniu jednoznacznie kwestię tę rozstrzyga znakomite studium Radosława Ptaszyńskiego. Przedstawione wyżej zastrzeżenia absolutnie nie obniżają jego wartości, wynikając z nieco odmiennej perspektywy badawczej, chcąc też zachęcić Autora do uwzględnienia kilku szerszych, kontekstowych interpretacji. Publikacja ta z pewnością stanowić będzie jedno z podstawowych opracowań dotyczących niezależnych katolików świeckich, którzy w Polsce Ludowej przyjęli na siebie rolę depozytariuszy międzywojennych imponderabiliów, ale i wyznawców twardych reguł politycznego realizmu.

\section{BIBLIOGRAFIA (REFERENCES)}

\section{Źródła archiwalne}

Archiwum Instytutu Pamięci Narodowej w Warszawie, sygn. IPN BU 01210/156, IPN BU 0648/56/1.

Archiwum Katolickiego Stowarzyszenia Civitas Christiana w Warszawie, Zespół akt dotyczących Aleksandra Bocheńskiego, sygn. VII A-305.

\section{Źródła drukowane}

Garlicki A., Z tajnych archiwów, Warszawa 1993. 


\section{Opracowania}

Bankowicz B., Stowarzyszenie PAX: między rzeczywistościa socjalizmu realnego a utopia socjalizmu wieloświatopogladowego, w: Doktryny. Historia. Władza. Księga dedykowana profesorowi Wiesławowi Kozubowi-Cembroniewiczowi z okazji czterdziestolecia pracy naukowej, red. A. Citkowska-Kimla, M. Kawior-Filo, B. Szlachta, Kraków 2009.

Bankowicz B., W labiryncie wieloświatopogladowości: Stowarzyszenie PAX między realizmem a rzeczywistościa, w: B. Bankowicz, A. Dudek, Ze studiów nad dziejami Kościoła i katolicyzmu w PRL, Kraków 1996.

Dudek A., Pytel G., Bolesław Piasecki. Próba biografii politycznej, Londyn 1990.

Engelgard J., Bolestaw Piasecki 1939-1956, Warszawa 2015.

Engelgard J., Wielka gra Bolestawa Piaseckiego, Warszawa 2008.

Friszke A., Między wojna a więzieniem 1945-1953. Młoda inteligencja katolicka, Warszawa 2015.

Jaszczuk A., Ewolucja ideowa Bolestawa Piaseckiego 1932-1956, Warszawa 2005.

Kaczorowski A.W., Jan Frankowski, w: Słownik biograficzny katolicyzmu społecznego w Polsce, t. 1: A-J, red. R. Bender, Lublin 1994.

Kimla P., Etyka w realizmie politycznym, "Czasopismo Prawno-Historyczne” 2014, 66, 2.

Kimla P., Historycy-politycy jako źródło realizmu politycznego. Tukidydes - Polibiusz - Machiavelli, Kraków 2009.

Kimla P., Realistyczne krytyki moralizatorstwa w polityce, w: Moralność i władza jako kategorie myśli politycznej, red. J. Justyński, A. Madeja, Warszawa 2011.

Kimla P., Realizm polityczny a Polska, w: Między sercem a rozumem. Romantyzm i realizm w polskiej myśli politycznej, red. A. Citkowska-Kimla, P. Kimla, E. Antipow, K. Konik, Kraków 2017.

Kosicki P.H., Personalizm po polsku. Francuskie korzenie polskiej inteligencji katolickiej, Warszawa 2016.

Majchrowski J., Geneza politycznych ugrupowań katolickich. Stronnictwo Pracy, grupa „Dziś i Jutro", Paris 1984.

Micewski A., Wspótrządzić czy nie kłamać? Pax i Znak w Polsce 1945-1976, Paryż 1978.

Morgenthau H.J., Polityka między narodami. Walka o potęgę i pokój, Warszawa 2010.

Mozgol R., Ryzykowna gra. Jak Aleksander Bocheński przyczynit się do powstania Dziś i Jutro, „Biuletyn Instytutu Pamięci Narodowej” 2007, 4 (75).

Orzełek A., Aleksander Bocheński wobec działalności i koncepcji Patriotycznego Ruchu Odrodzenia Narodowego, „Dzieje Najnowsze” 2018, 50, 1.

Orzełek A., Publicystyka Aleksandra Bocheńskiego wobec stanu wojennego w Polsce. Dylematy realizmu PAX-owca, w: Letnia Szkoła Historii Najnowszej 2015. Referaty, red. Ł. Kamiński, J. Szumski, Warszawa 2016.

Ptaszyński R., Powstanie Koła Posłów „Znak” w projekcie neopozytywizmu Stanisława Stommy, w: Wybory i referenda w PRL, red. S. Ligarski, M. Siedziako, Szczecin 2014.

Ptaszyński R., Stanisław Stomma. Szkic do portretu katolickiego intelektualisty, w: Sensus catholicus. Katolicy świeccy w Polsce Ludowej. Postawa - aktywność - myśl. Studia i szkice, red. R. Ptaszyński, T. Sikorski, Toruń 2004.

Ptaszyński R., "Stommizm” - racjonalizm i sztuka kompromisu, "Znak” lipiec-sierpień 2015, 722-723.

Sadkiewicz J., "Ci, którzy przekonać nie umieja”. Idee porozumienia polsko-niemieckiego w publicystyce Władysława Studnickiego i wileńskiego "Słowa” (do 1939), Kraków 2012.

Sensus catholicus. Katolicy świeccy w Polsce Ludowej. Postawa-aktywność - myśl. Studia i szkice, red. R. Ptaszyński, T. Sikorski, Toruń 2004.

Strzelecka M., Między minimalizmem a maksymalizmem. Dylematy ideowe Stanistawa Stommy i Janusza Zabłockiego, Toruń 2015. 


\section{Publicystyka}

A.S., Spór o ideę, „Tygodnik Powszechny” 16 II 1947, 3, 7 (100).

Bocheński A., Czemu Wieniawa nie strzegt, jak wierny syn, tej trumny?, „Słowo” 22 VI 1937, 16,174 (4738).

Bocheński A., Jeszcze o instynkcie narodowym i Panu J.E. Skiwskim, „Polityka” 25 VI 1938, 9, 14 (159).

Bocheński A., List do redakcji, „Polityka” 10 VI 1937, 8, 13 (127).

Bocheński A., Nasze nie ich, „Bunt Młodych” 15 VII 1933, 4, 43.

Bocheński A., O dyskusji nad Monte Cassino, „Tygodnik Powszechny” 10 XI 1946, 2, 45 (86).

Bocheński A., O imperialiźmie, o Skiwskim i o sprawie żydowskiej, „Polityka” 10 IV 1938, 9, 9.

Bocheński A., O pogromach słów parę, „Słowo” 19 VI 1937, 16, 166 (4730).

Bocheński A., Odpowiadam oponentom, „Tygodnik Powszechny” 16 II 1947, 3, 7 (100).

Bocheński A., Śmiertelne niebezpieczeństwo żydowskie, „Polityka” 25 XI 1937, 8, 28 (142).

Bocheński A., Zygzakiem przez prasę, „Bunt Młodych” 25 II 1937, 8, 5 (119).

Bocheński A., Rozmyślania krytyczne. Błą Zbigniewa Florczaka, „Kierunki” 27 V 1956, 1, 2.

Braun J., Bronię romantyzmu, „Tygodnik Warszawski” 15 II 1948, 4 , 7 (116).

Braun J., Katolicyzm a machiawelizm, "Tygodnik Warszawski” 21 III 1948, 4, 12 (21).

Cyprian T., Sawicki J., Polityka zagraniczna dwudziestolecia, „Tygodnik Powszechny” 8 XII 1946, 2, 49 (90).

Jasienica P., Polityczna waga heroizmu, „Tygodnik Powszechny” 17 XI 1946, 2, 46 (87).

Kieniewicz S., Nowy sąd nad historia, „Dziś i Jutro” 22 VI 1947, 3, 25 (82).

Kirchmayer W., Bohaterstwo i rozdział kompetencji, „Tygodnik Powszechny” 8 XII 1946, 2, 49 (90).

Lewicki M. ks., Co jest prawda, a co chimera, „Tygodnik Powszechny” 16 II 1947, 3 , 7 (100).

Lis M.W., O realizmie i polityce, „Tygodnik Powszechny” 16 II 1947, 3, 7 (100).

Łubieński K., Około „Wiadomości Literackich”. Do czynu, „Czas” 19 II 1933, 85, 41.

Mackiewicz J., Bunt rojstów, Londyn 2011.

Mackiewicz J., Optymizm nie zastapi nam Polski, Londyn 2013.

Malewska H., Realizm?, „Tygodnik Powszechny” 8 XII 1946, 2, 49 (90).

Meysztowicz J., Jeszcze "Dzieje głupoty”, „Dziś i Jutro” 10 VIII 1947, 3, 22 (89).

Pannenkowa I., Czy nie za wiele pesymizmu?, „Tygodnik Warszawski” 25 VIII 1946, 2, 34 (41).

Pannekowa I., Historia mistrzynia życia ale tylko prawdziwa. O racji stanu, ideologii, oraz madrości i głupocie politycznej, „Przegląd Kulturalny” 21 III-27 III 1957, 6, 12 (238).

Pannenkowa I., Mentorzy, "Tygodnik Warszawski" 7 II 1947, 3, 49 (108).

Pannenkowa I., Realizm, bohaterstwo - i bomba atomowa, „Tygodnik Warszawski” 11 V 1947, 3, $19(78)$.

Rostworowski S.K., O szkołe politycznego myślenia, „Dziś i Jutro” 13 VII 1947, 3, 28 (85).

Stomma S., Dostęp do Polski wspótczesnej, „Przegląd Kulturalny” 25 X-21 X 1956, 5, 43 (217).

Stomma S., Maksymalne i minimalne tendencje społeczne katolików w Polsce, "Znak” wrzesieńgrudzień 1946, 1, 3.

Stomma S., Pisma wybrane, t. 1: 1931-1939, t. 2: 1946-1975, t. 3: 1976-2003, red. R. Ptaszyński, Kraków 2017.

Straszewski M., Błędy polityki przedwrześniowej, „Tygodnik Powszechny” 8 XII 1946, 2, 49 (90).

Syrewicz K., Problem źle postawiony, „Tygodnik Powszechny” 8 XII 1946, 2, 49 (90).

Wydra F., Głos żotnierza, „Tygodnik Powszechny” 16 II 1947, 3, 7 (100). 


\section{ABSTRACT}

Radosław Ptaszyński's book about the life and political thought of Stanisław Stomma, covers important issues of political realism in the Polish intellectual tradition as well as points relevant to lay Catholics in the post-war period. The book presents Stomma as a politician and journalist who had to tackle the most important dilemmas of the Polish intelligentsia in the $20^{\text {th }}$ century. He was the creator of his own political thought system, "stommism". It was independent of conciliatory, realist and Romantic movements. I have minor objections regarding the context of the findings but I consider this publication very valuable.

Key words: biography, political thought, journalism, political realism, Stanisław Stomma

\section{NOTA O AUTORZE}

Ariel Orzełek (ur. w 1990 r.) - doktor nauk humanistycznych. Studia historyczne ukończył na Uniwersytecie Marii Curie-Skłodowskiej w Lublinie w 2014 r., doktorat uzyskał w roku 2018. Jego zainteresowania naukowe to: realizm polityczny w polskiej myśli politycznej i historycznej, środowiska katolików świeckich w Polsce powojennej, publicystyka polska doby najnowszej. Obecnie prowadzi badania nad postaciami i koncepcjami Jana Frankowskiego, Jerzego Hagmajera i Konstantego Łubieńskiego. Publikował m.in. w „Dziejach Najnowszych”, „Niepodległości” oraz W "Roczniku Lubelskim”. E-mail: ariel.k.orzelek@gmail.com 